\title{
Nutritional Status and Dietary Pattern of the Elderly in Tshiulungoma and Maniini Village of Thulamela Municipality, Vhembe District.
}

selekane motadi ( $\nabla$ selekane.motadi@univen.ac.za )

University of Venda https://orcid.org/0000-0002-7952-1348

Tshifhiwa Khorommbi

University of Venda

Lungile Maluleke

University of Venda

Research article

Keywords: Dietary pattern, Nutritional Status, Tshiulungoma and Maniini Village, Thulamela Municipality,

Vhembe

Posted Date: May 24th, 2021

DOI: https://doi.org/10.21203/rs.3.rs-521591/v1

License: (c) (i) This work is licensed under a Creative Commons Attribution 4.0 International License.

Read Full License 


\section{Abstract}

Introduction: Dietary patterns provide a comprehensive information about the food consumption habits within a population. Dietary patterns of every individual changes as we grow older. Dietary pattern of elderly is essential to the evaluation of their nutritional status. This study aimed to describe the nutritional status and dietary pattern of the elderly.

Methods: This was a cross sectional study involving elderly people aged 60 years and above. Socio demographic information was obtained from elderly people through a questionnaire. Dietary information was assessed using a questionnaire and dietary diversity score. Data on dietary intake were collected using Food Frequency Questionnaire (FFQ). Height and weight were measured. BMI were determined and classified using BMI category.

Results: A total of 300 elderly people had participated in the study, 150 from Maniini village and 150 from Tshiulungoma village. The prevalence of underweight, overweight and obesity was $2 \%, 34 \%$ and $17 \%$ respectively. Most (66\%) of the participants ate three meals per day. It was found that $13.7 \%$ of the elderly skipped breakfast every day. About $19.6 \%$ of elderly ate supper sometimes while $13.7 \%$ did not eat supper.

Conclusion: The findings of study reveals that most of the participants ate three main meals a day, with minority skipping either breakfast or dinner or eat in- between meals. Obesity was more prevalent in female as compared to the male counterparts. Improving nutritional status of elderly should follow an integrated approach tackling both malnutrition at the same time considering behavioural approach.

\section{Introduction}

Aging refers to irreversible continuous changes such as physiological, decline in physical and mental abilities which occur from birth to death and this changes may adversely affect food choice and dietary intake (Shatestein et al., 2013). The number of elderly people in the sub-Saharan Africa is expected to increase from 36.6 million to 141 million between 2005 and 2050, with the large proportion of them in the rural area (Kimokoti \& Hamer, 2008). Despite the epidemic of non-communicable and communicable disease life expectance has reduced by mother 30 years in various parts on the of the continent, the number of elderly people continue to rise in Africa. In South African the number of elderly people aged 60 years and above relative to those aged 59 and younger has increased over a period of 15 years from 1996-2011. The number of elderly people in South Africa has increased from 2.8 million in 1996 to 4.1 million in 2011 with Limpopo having $8.7 \%$ of the entire population of elderly people (Lehohla, 2014).

Appropriate nutrition is vital for elderly people because of the physiological changes that occur as one is aging (Agbozo et al., 2018). Loss of muscle mass, metabolic abnormalities and reduced immune function is the results of functional limitations and poor diet in most elderly people (Vellas et al.,2000). Good nutritional status and proper diet during aging is critical for boosting immune system and infection resistance (Pae, Meydani \& Wu, 2012). Eating variety of food to meet their nutritional need of their 
changing physiological state is very rare (Donini et al., 2013). Past experiences of food during childhood and earlier adulthood may influence attitudes concerning food and meals in later life (Edfors \& Westergren, 2012). However, Dietary pattern are not static and may change as the individual is aging.

South Africa like many developing countries is undergoing nutrition transition which promote and exacerbate weight gain in age groups. Even though dietary changes caused by these nutrition transition occur, undernutrition among elderly people still prevails especially in rural areas. In 2008 the prevalence of malnutrition in the sub-Saharan Africa varied according the country with Cameron (6\%), Ghana (48\%), Uganda (68\% for women and $32 \%$ for men) (Kimokoti \& Hamer, 2008). Overweight and obesity were prevalent in most sub-Saharan Africa countries with South Africa and Botswana having the highest number of obese women (Van der Sande et al., 2001; Kimokoti \& Hamer, 2008). However, Limpopo province $(77.1 \%)$ and Eastern cape $(64.4 \%)$ province where found to have the highest proportion of elderly people who are poor (Lehohla, 2014). In Limpopo province, deprived areas are mostly found in the rural areas where a considerable proportion of the population can be categorized as elderly. In view of this we conducted this study to evaluate the nutritional status and dietary pattern of elderly people in Thulamela municipality of Vhembe District.

\section{Materials And Methods}

A cross sectional study was carried out in 300 elderly people aged 60 years and above in Tshiulungoma and Maniini village of Thulamela Municipality, Vhembe District. Thulamela local municipality is the smallest municipality of four in the district, making up $10 \%$ of its geographical area. It is the largest municipality in the province in terms of population. The name Thulamela is a Karanga word meaning 'the place of giving birth. Data was collected during a three-month period (August to October 2019).

Simple random sampling was used to select Thulamela municipality from the four municipalities in the Vhembe District, Maniini and Tshiulungoma from 186 villages in Vhembe district. Convenience sampling was used to select study participants. A meeting with the elderly people was arranged at the chief's kraal. The researcher provided explanation on the aim, objectives and procedure of the study. Furthermore, the elderly people were given consent form to sign before data collection. All elderly people who agreed to participate were included, while those with cognitive deficits who were unable to respond to the interview were excluded. Furthermore, the study excluded elderly people who were in wheelchairs due to lack of equipment to measure their weight and height.

Data were collected by a team of trained health professionals (nutritionists and Biokineticists). Data was collected using a questionnaire and pilot tested to check for anything that could impede the instrument's ability to collect data in economical and systematic fashion. To ensure that the study participants recall food item consumed in the past given their age, food models were used. The following variables such as demographic data, dietary patterns, dietary diversity score as well as anthropometrics were measured. An expert from the Department of Linguistics at the University of Venda translated the questionnaire into the local language used in Thulamela Municipality which is Tshivenda to ensure that participants clearly 
understood the questions. Anthropometric assessments were performed according to standard procedure. The following measurements were taken in duplicate using calibrated equipment with the adult wearing light clothing and no shoes: standing height and weight. Height was measured to the nearest $0.1 \mathrm{~cm}$ using a calibrated portable Seca solar scale (Seca-model 0213, Hammer Steindamm, Hamburg, Germany) and weight was measured to the nearest $0.01 \mathrm{~kg}$ on a portable Seca solar scale (model 0213) (Seca, Hammer Steindamm, Hamburg, Germany). The solar scale and stadiometer were calibrated before measurements using a calibration weight and steel tape respectively (Lee \& Nieman, 2010).

\section{Food survey}

Food Frequency questionnaire was used to assess the dietary intake of elderly people. The adequacy of nutrients intake was compared with the recommended dietary intake for elderly people (Food and Nutrition Board, 2011). The dietary diversity score was interpreted using the WHO recommended cut-off point.

\section{Definition of underweight, Normal, Overweight and Obesity}

The BMI $\left(\mathrm{Kg} / \mathrm{m}^{2}\right)$ was selected to estimate the prevalence of underweight, overweight and obesity according to WHO references values. Underweight was defined as less $(<)$ 18.5, normal weight:

18.5 to 25 , Overweight: $25-29.5$ and Obesity: $>30 \mathrm{~kg} / \mathrm{m}^{2}$ (WHO, 1995).

\section{Statistical Analysis}

Statistical package of social sciences (IBM SPSS Statistics., Armonk, NY version 25) was used to analyze categorical and descriptive data such as mean, standard deviation, frequencies and percentages. Chisquare test for categorical data and Pearson's correlation were performed to assess the relationship between socio-demographic characteristics and nutritional status. A $p \leq 0.01$ and $p \leq 0.05$ was considered statistically significant. Food finder was used to analyze dietary intake of the study participants. The dietary diversity score was interpreted using the WHO recommended cut-off point.

\section{Results}

The socio demographic information of the study participants is summarized in Table 1. Half of the study participants had ages within 60-69 years. The mean (standard deviation (SD)) of the male participants was 70.04 (6.65) while that of female was 70.04 (6.65). Majority of the participants attended school. Of all those who attended school, $38.6 \%$ attended primary while $28.1 \%$ attended secondary school. Half of the participants were married. Almost all participants were receiving social grants. Most of the participants were Venda speaking while minority were Sepedi speaking. 
Table 1

Socio-demographic characteristics of study participants $(N=300)$

\begin{tabular}{|c|c|c|c|}
\hline \multirow[t]{3}{*}{ Variable } & \multicolumn{2}{|l|}{ Gender } & \multirow[t]{2}{*}{ Total number of participants } \\
\hline & \multicolumn{2}{|r|}{ Female } & \\
\hline & $n(\%)$ & $n(\%)$ & $n(\%)$ \\
\hline \multicolumn{4}{|l|}{ Age categories } \\
\hline$M( \pm S D)$ & $70.04(6.65)$ & $68.77(7.35)$ & \\
\hline $60-69$ years & $70(23)$ & $105(35)$ & $175(58)$ \\
\hline $70-79$ years & $47(16)$ & $44(15)$ & $91(31)$ \\
\hline 80 and above & $15(5)$ & $19(6)$ & $34(11)$ \\
\hline \multicolumn{4}{|l|}{ Educational level } \\
\hline Primary school & $55(18.3)$ & $61(20.3)$ & $116(38.6)$ \\
\hline Secondary school & $34(12)$ & $50(17)$ & $84(28.1)$ \\
\hline Never attended school & $43(14)$ & $57(19)$ & $100(33.3)$ \\
\hline \multicolumn{4}{|l|}{ Social grant } \\
\hline Receiving & $128(42.6)$ & $158(52.4)$ & $286(95)$ \\
\hline Not receiving & $4(1)$ & $10(3)$ & $14(5)$ \\
\hline \multicolumn{4}{|l|}{ Other source of income } \\
\hline Yes & $34(11)$ & $58(19)$ & $92(30)$ \\
\hline No & $99(33)$ & $111(37)$ & $208(70)$ \\
\hline \multicolumn{4}{|l|}{ Marital status } \\
\hline Single & $9(3)$ & $7(2)$ & $16(5)$ \\
\hline Married & $103(34)$ & $65(22)$ & $168(56)$ \\
\hline Divorced & $4(1)$ & $2(1)$ & $6(2)$ \\
\hline Widowed & $18(6)$ & $93(31)$ & $111(37)$ \\
\hline \multicolumn{4}{|l|}{ Ethnic group } \\
\hline Venda speaking & $132(44)$ & $162(54)$ & $294(98)$ \\
\hline Tsonga speaking & 0 & $6(2)$ & $6(2)$ \\
\hline
\end{tabular}




\begin{tabular}{|llll|}
\hline Variable & \multicolumn{2}{c|}{ Gender } & Total number of participants \\
\cline { 2 - 3 } & \multicolumn{3}{c|}{ Female } \\
\cline { 2 - 3 } & $n(\%)$ & $n(\%)$ & $n(\%)$ \\
\hline Christianity & $88(29)$ & & $134(45)$ \\
\hline Never attend church & $45(15)$ & $34(11)$ \\
\hline
\end{tabular}

The prevalence of underweight, overweight and obesity was $2 \%, 34 \%$ and $16.7 \%$ respectively. The prevalence of overweight and obesity was high in females $(18.7 \%$ and $11.7 \%)$ as compared to their male counterparts $(15.3 \%$ and $5 \%$ ). Sixty percent of the participants had medium dietary diversity score while $38 \%$ of the participants had the highest dietary diversity score. However, minority of the participants had the lowest dietary diversity score. This finding was not statistically significant $(p=0.064)$ (Table 2$)$. 
Table 2

Association between sociodemographic characteristics and nutritional status $(\mathrm{N}=300)$

\begin{tabular}{|c|c|c|c|c|c|}
\hline Characteristics & $\begin{array}{l}\text { Underweight } \\
\text { n (\%) }\end{array}$ & $\begin{array}{l}\text { Normal } \\
\text { n (\%) }\end{array}$ & $\begin{array}{l}\text { Overweight } \\
\text { n (\%) }\end{array}$ & $\begin{array}{l}\text { Obese } \\
\mathrm{n}(\%)\end{array}$ & P-value \\
\hline \multicolumn{6}{|l|}{ Gender } \\
\hline Male & $5(1.7)$ & $66(22)$ & $46(15.3)$ & $15(5)$ & \multirow[t]{2}{*}{0.043} \\
\hline Female & $1(0.3)$ & $76(25.3)$ & $56(18.7)$ & $35(11.7)$ & \\
\hline \multicolumn{6}{|l|}{ Age (years) } \\
\hline $60-69$ & $1(0.3)$ & $80(27)$ & $63(21)$ & $30(10)$ & \multirow[t]{3}{*}{0.824} \\
\hline $70-79$ & $2(0.7)$ & $44(14.7)$ & $31(10.3)$ & $15(5)$ & \\
\hline 80 and above & $3(1)$ & $18(6)$ & $8(2.7)$ & $5(1.7)$ & \\
\hline \multicolumn{6}{|l|}{ Educational level } \\
\hline Primary school & $3(1)$ & $66(22)$ & $48(16)$ & $20(6.7)$ & \multirow[t]{3}{*}{0.293} \\
\hline Secondary school & $0(0)$ & $30(10)$ & $20(6.7)$ & $12(4)$ & \\
\hline Never attended school & $3(1)$ & $46(15.3)$ & $34(11.3)$ & $18(6)$ & \\
\hline \multicolumn{6}{|l|}{ Social grant } \\
\hline Receiving & $6(2)$ & $141(47)$ & $97(32.3)$ & $42(14)$ & \multirow[t]{2}{*}{0.000} \\
\hline Not receiving & $0(0)$ & $1(0.3)$ & $5(1.7)$ & $8(2.7)$ & \\
\hline \multicolumn{6}{|l|}{ Other source of income } \\
\hline Yes & $3(1)$ & $34(11.3)$ & $31(10.3)$ & $24(8)$ & \multirow[t]{2}{*}{0.011} \\
\hline No & $3(1)$ & 108(36) & 71(23.7) & $26(8.7)$ & \\
\hline \multicolumn{6}{|l|}{ Marital status } \\
\hline Single & $0(0)$ & $10(3.3)$ & $6(2)$ & $1(0.3)$ & \multirow[t]{4}{*}{0.073} \\
\hline Married & $5(1.7)$ & 71(23.7) & $53(17.7)$ & $39(13)$ & \\
\hline Divorced & $0(0)$ & $5(1.7)$ & $2(0.7)$ & $0(0)$ & \\
\hline Widowed & $1(0.3)$ & $56(18.7)$ & 41(13.7) & $10(3.3)$ & \\
\hline \multicolumn{6}{|l|}{ Ethnic group } \\
\hline Venda speaking & $6(2)$ & $142(47.3)$ & $100(33.4)$ & $46(15.3)$ & \multirow[t]{2}{*}{0.033} \\
\hline Tsonga speaking & $0(0)$ & $0(0)$ & $2(0.7)$ & $4(1.3)$ & \\
\hline
\end{tabular}




\begin{tabular}{|c|c|c|c|c|c|}
\hline Characteristics & $\begin{array}{l}\text { Underweight } \\
\text { n (\%) }\end{array}$ & $\begin{array}{l}\text { Normal } \\
\mathrm{n}(\%)\end{array}$ & $\begin{array}{l}\text { Overweight } \\
\text { n (\%) }\end{array}$ & $\begin{array}{l}\text { Obese } \\
\text { n (\%) }\end{array}$ & P-value \\
\hline Christianity & $4(1.3)$ & 105(35) & $74(25)$ & $40(13.4)$ & \multirow[t]{2}{*}{0.803} \\
\hline Never attend church & $2(0.7)$ & $37(12.3)$ & $28(9.3)$ & $10(3.3)$ & \\
\hline
\end{tabular}

Table 3 provide the meal pattern of the study participants. Most (66\%) of the participants ate three meals per day. Of all the participants, most (86.3\%) of them ate breakfast every day while the minority (13.7\%) skipped breakfast. All participants ate lunch every day and $66.7 \%$ ate supper every day. However, $19.6 \%$ ate supper sometimes while $13.7 \%$ did not eat supper at all. Majority (84.3\%) did not eat snacks between meals. However, only the minority of the participants were drinking alcohol $(28 \%)$ and smoking $(12.7 \%)$. most (86.3\%) of them ate breakfast every day while the minority (5.3\%) skipped breakfast. All participants ate lunch every day and $66.7 \%$ ate supper every day. However, $19.6 \%$ ate supper sometimes while $13.7 \%$ did not eat supper at all. 
Table 3

Meal pattern of study participants

\begin{tabular}{|lll|}
\hline Variables & $n$ & $\%$ \\
\hline Number of main meals in a day & & \\
\hline Once per day & 0 & 0 \\
\hline Twice per day & 82 & 27.3 \\
\hline Three per day & 198 & 66 \\
\hline More than three times per day & 20 & 6.7 \\
\hline Breakfast skipping & & \\
\hline Yes & 41 & 13.7 \\
\hline No & 259 & 86.3 \\
\hline Breakfast & & \\
\hline Everyday & 259 & 86.3 \\
\hline Sometimes & 0 & 0 \\
\hline Do not eat & 41 & 13.7 \\
\hline Lunch & & \\
\hline Everyday & 216 & 72 \\
\hline Sometimes & & \\
\hline Do not eat & 300 & 100 \\
\hline Supper & 0 & 0 \\
\hline Everyday & 200 & 66.7 \\
\hline Sometimes & 59 & 19.6 \\
\hline Do not eat & 0 & 13.7 \\
\hline Eats snacks & & \\
\hline Yes & & \\
\hline No & & \\
\hline Alcohol intake & & \\
\hline Yes & & \\
\hline No & & \\
\hline
\end{tabular}




\begin{tabular}{|lll|}
\hline Variables & $\boldsymbol{n}$ & $\%$ \\
\hline Yes & 38 & 12.7 \\
\hline No & 262 & 87.3 \\
\hline
\end{tabular}

Majority (70.3\%) of the participants ate vitamin A rich vegetables and tubers 2-3 times per week while $29.7 \%$ ate vitamin A rich vegetables and tubers $4-6$ times per week. Moreover, $59.7 \%$ of the participants at vitamin A rich fruit 4-6 times per week as compared to $40.3 \%$ of the participants who ate vitamin A rich fruit 2-4 times per week. Most (96.3\%) of the participants ate dark green leafy vegetables 4-6 times per week while $3.7 \%$ ate dark green vegetable $2-3$ times per week. However, $37 \%$ of participants ate flesh meat 2-3 times per week. More than half (56\%) of the participants ate milk and milk products $2-3$ times per week (Table 4). 
Table 4

Frequency of different food groups intake by study participants in a week

\begin{tabular}{|c|c|c|}
\hline Food groups & $\begin{array}{l}\text { 2-3 times per } \\
\text { week } \\
n(\%)\end{array}$ & $\begin{array}{l}\text { 4-6 times per } \\
\text { week } \\
n(\%)\end{array}$ \\
\hline Cereals & 0 & $300(100)$ \\
\hline Vitamin A rich vegetables and tubers & $211(70.3)$ & $89(29.7)$ \\
\hline White tubers and roots & $58(19.3)$ & $242(80.7)$ \\
\hline Dark green leafy vegetables & 11(3.7) & $289(96.3)$ \\
\hline $\begin{array}{l}\text { Other vegetables (e.g. tomato, onion, eggplant), including wild } \\
\text { vegetables }\end{array}$ & $8(2.7)$ & 292(97.3) \\
\hline Vitamin A rich fruit & $121(40.3)$ & $179(59.7)$ \\
\hline Other fruits (other fruits, including wild fruits) & $214(71.3)$ & $86(28.7)$ \\
\hline Organ meat (iron rich) & $73(24.3)$ & 0 \\
\hline Flesh meats & $111(37)$ & 0 \\
\hline Eggs & $116(38.7)$ & 0 \\
\hline Fish & 195(65) & 0 \\
\hline Legumes, nuts and seeds & $216(72)$ & 0 \\
\hline Milk and milk products & $102(34)$ & 0 \\
\hline Oils and fats & 218(72.7) & $82(27.3)$ \\
\hline Sweets & 0 & 0 \\
\hline Spices, condiments, & $86(28.7)$ & 0 \\
\hline Beverages & 197(65.7) & 103(34.3) \\
\hline
\end{tabular}

Half of the participants did meet their energy intake while $49.8 \%$ did not meet their energy intake $(\mathrm{p}=$ 0.023). The mean intake of energy was $2345 \pm 942.35$. Of all the participants, $62.5 \%$ did not met their protein intake while $56.4 \%$ while $37.5 \%$ did meet their protein intake. The mean intake of protein was 45.3 \pm 19.4 while that of iron was $8.4 \pm 7.5$ and that of zinc was $11.2 \pm 10.8$. Almost sixty percent of the participants did not meet their vitamin B2 intake while only $40.2 \%$ did meet their vitamin B2 intake (Table 5). 
Table 5

Mean daily nutrient intake of the participants $(n=300)$

\begin{tabular}{|c|c|c|c|c|c|c|}
\hline \multirow[t]{2}{*}{ Nutrients (units) } & \multicolumn{3}{|c|}{ Mean daily intake } & \multirow{2}{*}{$\begin{array}{l}\text { Participants that } \\
\text { did not meet } \\
\text { reference intake }\end{array}$} & \multirow{2}{*}{$\begin{array}{l}\text { Participants that } \\
\text { met/exceeded } \\
\text { reference intake }\end{array}$} & \multirow{2}{*}{$\begin{array}{l}P \text { - } \\
\text { value }\end{array}$} \\
\hline & $\underset{S D}{M}( \pm$ & $R D A$ & Range & & & \\
\hline Energy Kcal & $\begin{array}{l}2345 \pm \\
942.35\end{array}$ & 2300 & $\begin{array}{l}1845- \\
2328\end{array}$ & 49.8 & 50.2 & 0.358 \\
\hline Carbohydrates $(g)$ & $\begin{array}{l}385 \pm \\
127.34\end{array}$ & 130 & $\begin{array}{l}93.4- \\
230.4\end{array}$ & 26.7 & 73.3 & 0.451 \\
\hline Protein (g) & $\begin{array}{l}45.3 \pm \\
19.4\end{array}$ & 56 & $\begin{array}{l}41.3- \\
78.2\end{array}$ & 62.5 & 37.5 & 0.046 \\
\hline Fats (g) & $\begin{array}{l}30.45 \\
\pm 27.6\end{array}$ & ND & $\begin{array}{l}12.2- \\
35.4\end{array}$ & 16.2 & 83.8 & 0.536 \\
\hline Calcium (mg) & $\begin{array}{l}845.23 \\
\pm \\
345.21\end{array}$ & 1000 & $\begin{array}{l}120.6- \\
984.5\end{array}$ & 56.4 & 43.6 & 0.023 \\
\hline Sodium $(m g)$ & $\begin{array}{l}1.2 \pm \\
0.94\end{array}$ & 1.3 & $\begin{array}{l}0.45- \\
1.18\end{array}$ & 32.2 & 67.8 & 0.674 \\
\hline Potassium ( $m g$ ) & $\begin{array}{l}4.9 \pm \\
4.6\end{array}$ & 4.7 & $\begin{array}{l}0.32- \\
4.89\end{array}$ & 72.7 & 27.3 & 0.523 \\
\hline Iron $(m g)$ & $\begin{array}{l}8.4 \pm \\
7.5\end{array}$ & 8 & $\begin{array}{l}7.6- \\
8.7\end{array}$ & 51.7 & 48.3 & 0.026 \\
\hline Zinc (mg) & $\begin{array}{l}11.2 \pm \\
10.8\end{array}$ & 11 & $\begin{array}{l}8.5- \\
11.45\end{array}$ & 50.3 & 49.7 & 0.013 \\
\hline Folate $(m g)$ & $\begin{array}{l}428.20 \\
\pm \\
415.23\end{array}$ & 400 & $\begin{array}{l}389.5- \\
486.7\end{array}$ & 43.2 & 56.8 & 0.034 \\
\hline Vitamin B1 $(m g)$ & $\begin{array}{l}0.80 \pm \\
0.57\end{array}$ & 1.2 & $\begin{array}{l}0.8- \\
1.29\end{array}$ & 61.6 & 38.4 & 0.672 \\
\hline Vitamin B2 $(m g)$ & $\begin{array}{l}0.84 \pm \\
0.53\end{array}$ & 1.3 & $\begin{array}{l}0.7- \\
136\end{array}$ & 59.8 & 40.2 & 0.026 \\
\hline Vitamin B6 (mg) & $\begin{array}{l}0.43 \pm \\
0.59\end{array}$ & 1.7 & $\begin{array}{l}0.24- \\
18.4\end{array}$ & 49.8 & 50.2 & 0.361 \\
\hline
\end{tabular}

Source: The Institute of Medicine of the National Academies (2002/2005).

ND: not determined

Academies (2002/2005). ND: not determined 


\begin{tabular}{|c|c|c|c|c|c|c|}
\hline \multirow[t]{2}{*}{ Nutrients (units) } & \multicolumn{3}{|c|}{ Mean daily intake } & \multirow{2}{*}{$\begin{array}{l}\text { Participants that } \\
\text { did not meet } \\
\text { reference intake } \\
n(\%)\end{array}$} & \multirow{2}{*}{$\begin{array}{l}\text { Participants that } \\
\text { met/exceeded } \\
\text { reference intake }\end{array}$} & \multirow{2}{*}{$\begin{array}{l}P \text { - } \\
\text { value }\end{array}$} \\
\hline & $\underset{S D}{M}( \pm$ & $R D A$ & Range & & & \\
\hline Vitamin C $(m g)$ & $\begin{array}{l}93.5 \pm \\
101.2\end{array}$ & 90 & $\begin{array}{l}86.5- \\
123.2\end{array}$ & 56.4 & 43.6 & 0.001 \\
\hline Vitamin A $(m g)$ & $\begin{array}{l}923 \pm \\
245.3\end{array}$ & 900 & $\begin{array}{l}784.6- \\
255.4\end{array}$ & 21.2 & 78.8 & 0.052 \\
\hline \multicolumn{7}{|c|}{ Source: The Institute of Medicine of the National Academies (2002/2005). } \\
\hline \multicolumn{7}{|c|}{ ND: not determined } \\
\hline \multicolumn{7}{|c|}{ Academies (2002/2005). ND: not determined } \\
\hline
\end{tabular}

\section{Discussion}

The ageing process is a biological reality which has its own dynamic, largely beyond human control (WHO, 2002). However, it is also depended on how each society makes sense of old age. Most elderly people in the current study were falling within the age range 60-69 years may reflect the picture of elderly in SA. The Older Persons Act 13 of 2006 in South Africa provides that an older person is a person who is 60 years old or older (Constitution of the Republic of South Africa, 1996). In African, elderly person is defined as age between 50 to 65 years, depending on the setting, the region and the country (Agbozo et al., 2018).

Our study examined the nutritional Status and dietary pattern of the elderly in Tshiulungoma village. We found low prevalence of underweight among elderly people, which was similar to previous study conducted in South Africa and other parts of Sub-Saharan countries (Kimokoti \& Hamer, 2008; Van der Sande et al., 2001). This study support Mahan and Escott-Stump (2012), the actual prevalence of underweight among older adults is quite low, many adults are at risk for undernutrition and malnutrition. Underweight among elderly people may be due to poor mobility, inability to purchase and prepare food (Aganiba et al., 2015). Our data found that $34 \%$ of elderly people were overweight while $16.7 \%$ were obese. These findings are congruent with previous study that indicated that South Africa had the highest rate of overweight and obesity (Van der Sande et al., 2001). The prevalence was of overweight was slightly higher in elderly women (18.7\%) as compare to $15.3 \%$ of elderly men while obesity was higher in elderly women $(11.7 \%)$ as compared to $5 \%$ of elderly men. Similar findings were observed in sub-Saharan countries like South Africa, Ghana, Kenya, Senegal, Uganda, Botswana and Cameroon (Kimokoti \& Hamer, 2008; Van der Sande et al., 2001; Cheserek et al., 2012; Agbozo et al., 2018). The findings of this study support Mahan and Escott-Stump (2012), prevalence of obesity has increased in all ages, older adults are no exception, obesity rates are greater among those ages 65 to 74 than among those ages 75 and over and over and obesity is associated with increase in mortality and contribute to many chronic diseases. 
Prevalence of obesity and overweight could be due to the fact that aging is associated with a decrease in total energy expenditure, and if this coincides with a maintained or increased energy intake, overweight/obesity may develop (Edfors \& Westergren, 2012). However, the socioeconomic disparities, poor nutritional qualities of traditional diets in many rural communities could not be ruled as they might have contributed to malnutrition among elderly people. Under and overnutrition among elderly coexist in the current study like many Sub-Saharan countries (Alao, Akinola \& Ojofeitimie, 2015; Maila, Audain \& Marinda, 2019). The prevalence of obesity was high among $13 \%$ female as compared to their male $4 \%$ counterparts (Mittal \& Srivastava, 2006). This may be due to the fact that women are heavier than males while males are taller than females and in South Africa overweight and obesity is associated with "wealth and healthy" but the perception has drastically changed on the basis that overweight and obesity are associated with many non-communicable diseases (Motadi et al., 2015)

The nutrition and health of the elderly is often neglected. Most nutritional intervention programs are directed toward infants, young children, adolescents, and pregnant and lactating mothers (Agarwalla, Saikia \& Baruah, 2015). Every community has its own pattern and practices, with ideas as to which foods are good for the people at different ages and which one are not. What people think about food is also affected by what is available. Most of the elderly people know the nutritional values of the foods they eat. Some avoid certain foods because of personal dislike, social and cultural practices and religion. The dietary pattern of the participants shows that most of them ate three main meals a day which is necessary for good health. This is similar to findings from a study carried out among elderly in rural Southern African countries (Lee et al., 1996). As shown by Shahar et al. (2003) the older population tends to continue the more traditional eating pattern of three meals a day. However, minority of them either skip breakfast or eat in- between meals. Minority of the participants sometimes skip breakfast or dinner. Skipping of meals is a very common practice among elderly people in the rural areas (Lee, Templeton \& Wang, 1996). Minority of the participants in the current study snacked in between meals possibly to enable them cope with the energy needs of the body as they go about their daily activities. However, Lee et al. (1996) reported low intake of nutrient among elderly people who snacked frequently. The pattern also shows a low intake of snacks, alcohol and tobacco use among them.

The findings on food consumption revealed that many participants in the current study consumed food from different food groups. However, most of the participants consumed fruits, vegetables and cereals. Protein food sources were rarely consumed except that participants consumed legumes, nuts and seeds 2-3 times per week. These findings are congruent with previous studies that reported high intake of vegetables and cereals among older persons in South Africa (Govender, 2011) and Zambia (Maila et al., 2019). Additionally, maize meal porridge is one of the staple foods in the South African diet and is usually consumed with green leafy vegetables and a small amount of animal-derived food (Labadarios et al., 2005). The rarely consumption of this animal derived food sources could be due their high cost, limited supply and in some cases, due to religious or cultural practices. Insufficient consumption of these animal food source leads to low intake of important micronutrients among this age group (Roohani et al., 2013). 
Our study showed low consumption of milk and milk product among the participants. Perhaps this can be attributed to the fact that milk is perceived as tasteless by most elderly people due to deterioration of taste buds. Between 75 and 85 years, the taste buds' deterioration is $65 \%$ reduction of sensitivity to sweet and salty taste. One of the well-established factors that affect food choice is the sensory perceptions to food stimuli. Chemical and physical properties of the food are perceived by the individual in terms of sensory attributes. These sensory attributes of foods can be categorized, in broad terms, as appearance, texture, trigeminal mouth feel, odour and taste (Shepherd, 1999; Alao et al., 2015). The ability to perceive these sensory attributes in addition to liking them determines whether an individual consumes a food (Shepherd, 1999; Mahan \& Escott-Stump, 2012). The low consumption of milk and dairy product can explain the reason why participants didn't meet their dietary intake of calcium. Congruently, in Zambia Maila et al. (2011) reported low consumption of milk and milk product. In Kenya Munoru (2018) reported high consumption of milk among elderly people. In addition, Chollet et al. (2014) reported higher percentage of $96 \%$ in the consumption of dairy products in Switzerland.

About (38\%) of the study participants had the highest dietary diversity score. This may be due to the fact that almost all participants received social grant. A social grant is given to qualifying poor households as an important contributor in reducing poverty and food insecurity in South Africa. Socioeconomic status plays a vital role in quality of life, including the food choices that these elderlies can make (Mkhize, Napier \& Oldewage-Theron, 2013). However, Study conducted by Chakona and Shackleton (2019) in South Africa revealed that grant recipients do not use the money for food only but also on other household necessities instead of taking care of the beneficiaries' own needs. Alao et al. (2015) revealed that income remains a strong determinant in the choice of food consumed by the elderly people. Furthermore, highest dietary score may be linked to overnutrition observed among study participants as indicated by the prevalence of overweight and obesity.

Almost half of the participants didn't meet their energy intake in the current study. Alao et al. (2015) reported that older who may not eat enough to meet energy needs which can results in increases the risk of nutrition related illness. Our study revealed that even though many participants consumed food from different food groups, it is also noticed from the result of the study that participants didn't meet the dietary intake of iron, zinc, calcium, vitamin B1, B2 and vitamin C. These may be attributed to the agerelated alterations to the sense of taste which is closely linked to poor appetite, inappropriate food choices, and lower nutrient intake. This insufficient intake of micronutrients may be due to the fact that the participants reported low intake of protein. Protein share the same food sources with zinc, iron, vitamin B1 and B2 (Mahan \& Escott-Stump, 2012).

The limitation of the present study was that the information on dietary intake relied on the ability of the participants to recall, which might have resulted in under and overreporting. The study was conducted in two villages which cannot be generalized to Thulamela municipality.

\section{Conclusion}


The study reveals that most of the participants ate three main meals a day, with minority skipping either breakfast or dinner or eat in- between meals. Consumption of food from different food groups ensures balanced nutrition even though very few had highest dietary diversity score. BMI status of the study participants indicate that most of them had a normal weight. This study reveals that even though elderly people are known to be more knowledgeable about the role and importance of nutrition, it does not imply an improvement in dietary intakes. Understanding of dietary patterns of older people is necessary for providing appropriate nutritional guidance. Nutrition education to encourage healthy eating among elderly people should include family support.

\section{Abbreviations}

WHO: World Health Organization.

BMl: Body Mass Index

\section{Declarations}

\section{Acknowledgments:}

The authors would like to acknowledge the University of Venda and health professionals assisting with data collection. Furthermore, we would like to pass our message of appreciation to elderly people for their participation and cooperation.

\section{Funding:}

This research study received no funding.

\section{Availability of data and materials:}

The datasets used and/or analyzed during the current study are available from the corresponding author on request.

\section{Authors' contributions:}

$\mathrm{KT}$ and $\mathrm{ML}$ collected the data. MSA analyzed the data. MSA, KT, and ML contributed materials/analysis tools. MSA prepared the draft manuscript. MSA, KT and ML finalized the manuscript and provided a critical review. All authors have read and approved the final manuscript.

\section{Ethical Considerations:}

The study was approved by University of Venda Research Ethics Committee and the Ethical clearance certificate was issued (SHS/19/NUT/12/2405) and the permission to conduct the study was granted by the Limpopo Provincial Department of Health Research Committee. The study was performed in accordance with principles of the Declaration of Helsinki (2008), Good Clinical Practices and the laws of 
South Africa. A full and adequate oral and written explanation of the study was given to the participants. Participants gave written signed informed consent to participate in the study. The consent form included the participants' right to withdraw from the study and codes were used to ensure confidentiality of the information obtained.

\section{Consent to publication:}

The manuscript does not contain any individual person's data in any form.

\section{Competing interests:}

The authors declare that they have no competing interests.

\section{References}

1. Aganiba BA, Owusu WB, Steiner-Asiedu M \& Dittoh S (2015). Association between lifestyle and health variables with nutritional status of the elderly in the northern region of Ghana. Afr $J$ Food Agric Nutr Dev 15(4):10198-10216.

2. Agarwalla R, Saikia AM \& Baruah R (2015). Assessment of the nutritional status of the elderly and its correlates. J Family Community Med 22(1): 39.

3. Agbozo F, Amardi-Mfoafo J, Dwase H \& Ellahi B (2018). Nutrition knowledge, dietary patterns and anthropometric indices of older persons in four peri-urban communities in Ga West municipality, Ghana. Afr Health Sci 18(3): 743-755.

4. Alao MT, Akinola 00 \& Ojofeitimie $O$ (2015). Dietary Intake and Nutritional Status of the Elderly in Osun State (2). IOSR Journal of Nursing and Health Science (IOSR-JNHS) 4(1): 32-35.

5. Cederholm T, Barazzoni R, Austin P, Ballmer P, Biolo G, Bischoff SC \& Jensen GL (2017). ESPEN guidelines on definitions and terminology of clinical nutrition. Nutr 36(1): 49-64.

6. Chakona G \& Shackleton CM (2019). Food insecurity in South Africa: To what extent can social grants and consumption of wild foods eradicate hunger?. World Development Perspectives 13: 8794.

7. Chollet M, Gille D, Piccinali P, Bütikofer U, Schmid A, Stoffers H \& Walther B (2014). Dairy consumption among middle-aged and elderly adults in Switzerland. J Dairy Sci 97(9): 5387-5392.

8. Cheserek MJ, Tuitoek PJ, Waudo JN, Msuya JM \& Kikafunda JK (2012). Anthropometric characteristics and nutritional status of older adults in Lake Victoria Basin East Africa: region, sex, and age difference. SAJCN25(2):67-72.

9. Donini LM, Scardella P, Piombo L, Neri B, Asprion R, Projetti AR, Carcaterra S, Cava E, Cataldi S, Cucinotta D \& Di Bella G (2013). Malnutrition in elderly: social and economic determinants. J Nutr Health Aging 17(1):9-15

10. Edfors E \& Westergren A (2012). Home-living elderly people's views on food and meals. Aging Res 2012. DOI:10.1155/2012/761291. 
11. 1 Govender T (2011). Analysis of the nutritional status and dietary intake data of a group of elderly at a day and frail care centre in Verulam (Doctoral dissertation). Durban University of Technology, Durban.

12. 1Kaiser MJ, Bauer JM, Rämsch C, Uter W, Guigoz Y, Cederholm T \& Tsai AC (2010). Frequency of malnutrition in older adults: a multinational perspective using the mini nutritional assessment. $J \mathrm{Am}$ Geriatr Soc 58(9): 1734-1738.

13. 1Kimokoti RW\& Hamer DH (2008). Nutrition, health and aging in Sub-Saharan Africa. Nutr Rev 66(11)611-23.

14. Labadarios D, Steyn NP, Maunder E, Macintryre U, Gericke G, Swart R \& Nel JH (2005). The national food consumption survey (NFCS): South Africa, 1999. Public Health Nutr. 8(5): 533-543.

15. Lehlohla P (2014). Census 2011: Profile of older persona in South Africa. Statistics South Africa. Pretoria.

16. 1Lee CJ, Templeton S \& Wang C (1996). Meal skipping patterns and nutrient intakes of rural southern elderly. $J$ Nutr Elder 15(2): 1-14.

17. Mahan LK \& Escott-Stump S (2012). Krause's Food \& Nutrition care process 13th ed. Elsevier 434 Saunders, St Louis Missouri.

18. 1 Maila G, Audain K \& Marinda PA (2019). Association between dietary diversity, health and nutritional status of older persons in rural Zambia. S Afr J Clin Nutri 16: 1-6. DOI: 10.1080/16070658.2019.1641271.

19. Mittal P \& Srivastava S (2006). Diet, nutritional status and food related traditions of Oraon tribes of New Mal (West Bengal), India. Rural and Remote Health 6(385):1-11.

20. Mkhize X, Napier C \& Oldewage-Theron W (2013). The nutrition situation of free-living elderly in Umlazi township, South Africa. Health SA Gesondheid (Online) 18(1): 1-8.

21. 2Motadi SA, Mbhenyane XG, Mbhatsani HV, Mabapa NS \& Mamabolo RL (2015). Prevalence of iron and zinc deficiencies among preschool children ages 3 to $5 \mathrm{y}$ in Vhembe district, Limpopo province, South Africa. Nutri 31(3): 452-458.

22. Munoru FK (2018). Dietary and care practices, morbidity and nutritional status of the elderly in Igembe South, Meru county, Kenya (Doctoral dissertation). Kenyatta University, Kenya.

23. Pae M \& Meydani SN,Wu D (2012). The role of nutrition in enhancing immunity in aging. Aging Dis $3(1): 91$

24. Republic of South Africa. The Constitution of the Republic of South Africa. Act 108 of 1996, Section 27 [Online]. From http://www.info.gov.za/documents/constitution/. [Retrieved May15 2020].

25. Roohani N, Hurrell R, Kelishadi R \& Schulin R (2013). Zinc and its importance for human health: An integrative review. Journal of research in medical sciences (J Res Med Sci) 18(2):144.

26. Shahar D, Shai I, Vardi H \& Fraser D (2003). Dietary intake and eating patterns of elderly people in Israel: who is at nutritional risk. Eur J Clin Nutr 57(1): 18-25. 
27. 2Shatenstein B, Gauvin L, Keller H, Richard L, Gaudreau P, Giroux F \& Payette H (2013). Baseline determinants of global diet quality in older men and women from the NuAge cohort. $J$ Nutr Health Aging 17(5): 419-425.

28. Shepherd R (1999). Social determinants of food choice. Proc Nutr Soc 58(4): 807-812.

29. Vellas B, Gillette-Guyonnet S, Nourhashemi F, Rolland Y, Lauque S, Ousset PJ, Moulias S, Andrieu S, Fontan B, Adoue D \& Lafont C (2000). Falls, frailty and osteoporosis in the elderly: a public health problem. Rev Med Interne 21(7):608.

30. Van der Sande MA, Coleman RL, Schim van der Loeff MF, McAdam KP, Nyan OA, Thien T, Dolmans WM \& Walraven GE (2001). A template for improved prevention and control of cardiovascular disease in sub-Saharan Africa. Health policy and planning 16(4):345-350.

31. World Health Organization (2002). Cardiovascular Disease Programme, World Health Organization, Cardiovascular Disease Programme (World Health Organization), World Health Organization. Noncommunicable Disease, \& Mental Health Cluster (2002). Integrated management of cardiovascular risk. World Health Organization, Geneva. 